\title{
Viability of Small Enterprise and the Enlargement of Inward Occasion to Progression Its Capacity
}

\author{
Jamshid Doniyerovich Akramov ${ }^{1)}$, Tashmuxamedova Karima Samatovna ${ }^{2)}$ \\ ${ }^{1)}$ Master of Department "Economy and Real Estate Management" Tashkent Institute of Architecture and \\ Civil Engineering, Tashkent, Uzbekistan \\ ${ }^{2)}$ Associate professor of department "Economy and Real Estate Management" Tashkent Institute of \\ Architecture and Civil Engineering, Tashkent, Uzbekistan.
}

Email: jasrash55@gmail.com ${ }^{1)}$

\begin{abstract}
This research paper argues that common growth figures are not a assure of high profitability. This is, it become observed that a number of functions of the marketplace position of companies and their ownersmanagers have a poor effect on profitability and boom fees, and the extent of profitability stays above the average for a very brief time. The efficiency of small companies is enormously dependent on approach preference, whilst turnover increase is specifically depending on strategy.
\end{abstract}

Keywords: Evaluation, Profitability, Small Enterprise, Quantity Enhancement, Production Industry, Value.

\section{Introduction}

The modern market environment is dynamic and changeable. Changes in tastes and demands of consumers, innovations in technologies, management methods are constantly taking place. All this opens up competitive advantages for small and medium-sized businesses over large enterprises, of which the most important are: responsiveness to changes in market conditions, described as a technology for monitoring the situation in the corresponding market segment, identifying needs, transforming the identified need into a project, designing a new product or service, and etc; low overhead costs due to the functional use of all personnel of a small enterprise for the production of added value, attributed to the cost of goods produced or services rendered; focus on the continuous implementation of the capabilities of the rapid technology update; constancy of innovative behavior as an increase in the speed of innovation in all areas of a small enterprise (from manufactured products and services provided to the use of new management technologies, employee motivation, etc.); search for forms of access to borrowed financial resources of large enterprises, taking on the risk of the feasibility of those types of work that are not economically feasible for large business to develop; use of new technologies of marketing research and active advertising available to small businesses.

The development industry is one of the sectors of the countrywide economy in Uzbekistan, which has a stable increase rate a number of the sectors of the national economy. The action strategy for the further development of the Republic of Uzbekistan for 2017-2021, evolved and followed on the initiative of the President of the Republic of Uzbekistan Sh.Mirziyoyev, states: improving the mechanism of knowledge, the usage of modern sorts of construction substances are a number of the priorities.

Today in Uzbekistan there are more than 24.1 thousand construction companies. In 2019 alone, 38.1 thousand small businesses and private entrepreneurs were created, of which $13 \%$ or 4953 were in the construction sector, and about $9.7 \%$ of the country's GDP was created directly in the construction sector [1]. 


\section{Methods of research}

Financial result is a basic concept in the characterization of the financial position of the enterprise. The financial result can be expressed in the form of profit or in the form of loss.

The financial results of an enterprise serve as a kind of indicator of its importance in the national economy. In market conditions of management, any enterprise is interested in obtaining a positive result from its activities, since due to the value of this indicator, the enterprise is able to expand the material and technical base, increase the volume of production, update the range of products, materially motivate personnel, working at the given enterprise, pay dividends to shareholders, etc.

Despite the fact that in the economic literature there are a lot of studies devoted to improving the financial results of enterprises, optimizing the processes of formation, distribution and use of profits, there is no single definition of the concepts of financial result and profit [2].

The level of competitiveness in modern market conditions is one of the main indicators characterizing the success of enterprises. In order to maintain and enhance market position, enterprises need to develop their competitive advantages. Organizations strive to make the most of the resources at their disposal to provide a competitive advantage over competitors.

Business development involves not only the efficient use of buildings, structures, equipment, inventories of materials, funds, but also the establishment of relationships with suppliers and customers, customer base, highly qualified personnel and many other similar components $[3,4]$. Particular attention should be paid to the development of the supplier base, customer base and order portfolio, as the obligations to establish a stable and long-term relationship with the customer and supplier must be fulfilled in a timely manner, in general, to conduct business conscientiously. Also, the convenience of the location of the company's offices or retail outlets, their operating hours, the speed and quality of service, and of course, the communication culture play an important role.

\section{Results}

The availability of highly qualified personnel is of particular importance for the development of the company.

Profit is an economic category, which is a generalized indicator of the financial results of economic activity, which is defined as the difference between the income of the enterprise and the costs associated with the implementation of this activity, calculated in monetary terms.

\section{Conclusion}

As an monetary class, profit plays the subsequent features:

Firstly, the earnings characterizes the monetary impact received as a result of the activity of the business enterprise;

Secondly, earnings has a stimulating feature. Its content lies in the truth that it's miles both the monetary end result and the main element of the financial resources of the enterprise. The real provision of the precept of self-financing is determined via the profit received. The share of the internet earnings final on the disposal of the organization after paying taxes and different obligatory payments have to be enough to finance the expansion of manufacturing sports, clinical, technical and social improvement of the business enterprise, fabric incentives for personnel; 
Thirdly, income is one of the resources of budgeting at distinct levels. It enters the budgets within the shape of taxes and, along side other earnings receipts, is used to finance and satisfy joint public needs, make sure the nation's overall performance of its features, state investment, and production, medical, technical and social packages.

\section{References:}

https://strategy.uz/index.php?news=1231

King, Andrew, and Michael Lenox. "Exploring the locus of profitable pollution reduction." ManagementScience 48.2 (2002): 289-299.

Cerbioni, Fabrizio, and Antonio Parbonetti. "Exploring the effects of corporate governance on intellectual capital disclosure: an analysis of European biotechnology companies." EuropeanAccountingReview 16.4 (2007): 791-826.

Mustafakulov, Sherzod. "Investment Attractiveness of Regions: Methodic Aspects of the Definition and Classification of Impacting Factors." EuropeanScientificJournal 13.10 (2017): 433-449.

Golovko, Elena, and Giovanni Valentini. "Exploring the complementarity between innovation and export for SMEs' growth." JournalofinternationalbusinessStudies 42.3 (2011): 362-380.

Tamulevičienè, Daiva. "Methodology of complex analysis of companies' profitability." Entrepreneurshipandsustainabilityissues 4 (2016): 53-63.

Roper, Stephen. "Modelling small business growth and profitability." SmallBusinessEconomics 13.3 (1999): 235-252.

Moore, Samuel B., and Susan L. Manring. "Strategy development in small and medium sized enterprises for sustainability and increased value creation." Journalofcleanerproduction 17.2 (2009): 276-282.

Langerak, Fred, Erik Jan Hultink, and Abbie Griffin. "Exploring mediating and moderating influences on the links among cycle time, proficiency in entry timing, and new product profitability." JournalofProductInnovationManagement 25.4 (2008): 370-385.

Нормуродов, С. Н., and Ж. Г. Рашидов. "ОСОБЕННОСТИ МАРКЕТИНГА В СТРОЙИНДУСТРИИ В РЫНОЧНЫХ УСЛОВИЯХ." Социально-экономическое развитие городов и регионов: градостроительство, развитие бизнеса, жизнеобеспечение города. 2018.

Attaran, Mohsen. "Exploring the relationship between information technology and business process reengineering." Information\&management 41.5 (2004): 585-596.

Davidsson, Per, Leona Achtenhagen, and Lucia Naldi. "Research on small firm growth: A review." 35th EISB Conference: Sustaining the Entrepreneurial Spirit over Time: Implications for Young Companies, Family Businesses, and Established Companies. IESE BusinessSchool, 2005.

Basu, Anuradha. "An exploration of entrepreneurial activity among Asian small businesses in Britain." Smallbusinesseconomics 10.4 (1998): 313-326.

Lerner, Josh. "An empirical exploration of a technology race." The Rand Journal of Economics (1997): 228-247. 